Salt transport in the Irminger Current
A. Born et al.

\title{
Coupling of eastern and western subpolar North Atlantic: salt transport in the Irminger Current
}

\author{
A. Born ${ }^{1,2}$, T. F. Stocker ${ }^{1,2}$, and A. B. Sandø $\varnothing^{3,4}$ \\ ${ }^{1}$ Climate and Environmental Physics, Physics Institute, University of Bern, Bern, Switzerland \\ ${ }^{2}$ Oeschger Centre for Climate Change Research, Bern, Switzerland \\ ${ }^{3}$ Institute for Marine Research, Bergen, Norway \\ ${ }^{4}$ Bjerknes Centre for Climate Research, Bergen, Norway
}

Received: 22 February 2013 - Accepted: 7 March 2013 - Published: 15 March 2013

Correspondence to: A. Born (born@climate.unibe.ch)

Published by Copernicus Publications on behalf of the European Geosciences Union.

\section{Title Page}

\section{Abstract} Introduction

Conclusions References

Tables Figures

14

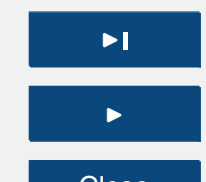

Back

Close

Full Screen / Esc

Printer-friendly Version

Interactive Discussion 


\section{Abstract}

Salt transport in the Irminger Current and thus the coupling between eastern and western subpolar North Atlantic plays an important role for climate variability across a wide range of time scales. High-resolution ocean modeling and observations indicate that 5 salinities in the eastern subpolar North Atlantic decrease with enhanced circulation of the North Atlantic subpolar gyre (SPG). This has led to the perception that a stronger SPG also transports less salt westward. In this study, we analyze a regional ocean model and a comprehensive global coupled climate model, and show that a stronger SPG transports more salt in the Irminger Current irrespective of lower salinities in its 10 source region. The additional salt converges in the Labrador Sea and the Irminger Basin by eddy transports, increases surface salinity in the western SPG, and favors more intense deep convection. This is part of a positive feedback mechanism with potentially large implications for climate variability and predictability.

\section{Introduction}

15 The Atlantic subpolar gyre (SPG) has repeatedly been identified as one important focal area of decadal variability in the Atlantic Ocean, and a potential source for improved decadal climate predictions (Delworth et al., 1993; Eden and Willebrand, 2001; Häkkinen and Rhines, 2004; Spall, 2008; Yoshimori et al., 2010; Born and Mignot, 2011; Robson et al., 2012; Yeager et al., 2012). However, its importance is attributed mostly to the passive advection of surface salinity anomalies of remote origin. The active creation of salinity anomalies by the anomalous SPG circulation itself is rarely considered.

A strong decline in the SPG circulation strength during the 1990s was first comprehensively described in observations by Häkkinen and Rhines (2004), who quantified variations with a "gyre index", the first Empirical Orthogonal Function (EOF) of the satellite altimeter sea surface height. Subsequent work with a regional ocean general
OSD

$10,555-579,2013$

Salt transport in the Irminger Current

A. Born et al.

\section{Title Page}

Abstract Introduction

Conclusions References

Tables Figures

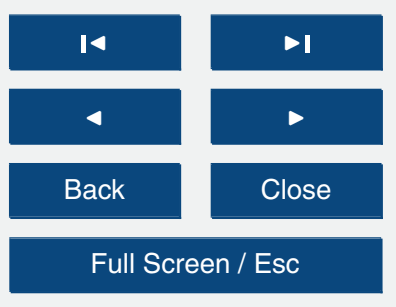

Printer-friendly Version

Interactive Discussion 
circulation model forced by reanalysis data confirmed this finding and associated the weakening of the SPG with a receding subpolar front and therefore high salinities in the eastern subpolar North Atlantic (Hátún et al., 2005b). This westward shift of the subpolar front also corresponds to more surface drifters released in subtropical waters 5 reaching the eastern subpolar North Atlantic (Häkkinen and Rhines, 2009).

In the climatological average, relatively saline waters of the eastern basin are advected westward by the Irminger Current where they enter the dynamically sensitive region of the western subpolar North Atlantic. Recent work suggests that positive salinity anomalies in the east resulting from a weak SPG are communicated in the same 10 way (Häkkinen et al., 2011). Paleoclimatic studies extended this concept concluding that a weak SPG enhances Labrador Sea convection through the additional salt transport and thereby strengthens the SPG again-effectively stabilizing the SPG and deep overturning in a negative feedback mechanism (Thornalley et al., 2009). However, the decrease in volume transport counteracts the positive salinity anomaly, with a priori uncertain consequences for the transport of salt and the resulting water mass in the western basin.

In this study, we describe how salt transport in the Irminger Current increases with a stronger SPG, as part of a positive feedback mechanism. We employ a simulation of the preindustrial millennium (850-1850 AD) with the comprehensive global climate model CCSM4, driven only by external forcing, and a hindcast simulation of the years 1950-2002 with a regional version of the ocean model MICOM, constrained by observational hydrography and known air-sea fluxes. Both models agree that salt transport in the Irminger Current increases with a stronger SPG, because the increase in volume transport overcompensates lower salinities in its source region by approximately two orders of magnitude. Time average circulation and the pattern of variability of the SPG circulation are similar in both models, suggesting that the current generation of climate models reproduces this important aspect of climate variability with reasonable detail.
OSD

$10,555-579,2013$

Salt transport in the Irminger Current

A. Born et al.

\section{Title Page}

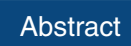

Introduction

Conclusions

References

Tables

Figures

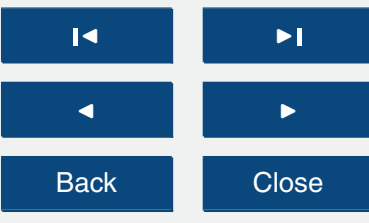

Full Screen / Esc

Printer-friendly Version

Interactive Discussion 
This paper is organized as follows. Section 2 describes the models used. Section 3 discusses how the SPG changes salt transport in the two models and in observations. We summarize and conclude in the final Sect. 4.

\section{Model description}

5 The simulation results used in this paper are obtained from two general circulation models, the regional Nansen Centre version of the Miami Isopycnal Ocean Model (MICOM) (Hátún et al., 2005a,b; Eldevik et al., 2005; Mauritzen et al., 2006; Sandø and Furevik, 2008) and the global coupled Community Climate System Model version 4 (CCSM4, Gent et al., 2011). While the regional model simulates the period from 1950 10 to 2002 using re-analysis data for atmospheric fluxes and hydrographic surface fields, the coupled global model is forced only by variations in external parameters between 850 and 1850 AD.

The regional version of MICOM has a horizontal resolution of approximately $20 \mathrm{~km}$ in the region of interest, nested within a global version of the same model with half 15 the resolution (Furevik et al., 2002; Nilsen et al., 2003; Bentsen et al., 2004). Both versions share a vertical resolution of 26 density levels, of which the mixed layer has a variable density and the lower 25 levels vary in thickness defined by fixed isopycnals. The regional refinement covers the Atlantic Ocean between $30^{\circ} \mathrm{N}$ and $78^{\circ} \mathrm{N}$ and applies a one-way boundary relaxation scheme toward the global model. Daily mean

20 NCAR/NCEP re-analysis data (Kistler et al., 2001) of fresh water, heat and momentum fluxes are used to force the system by applying the scheme of Bentsen and Drange (2000). In addition, in the regional sub-domain, the mixed layer temperature and salinity fields are linearly relaxed towards the monthly mean climatological values of Levitus and Boyer (1994) and Levitus et al. (1994), respectively. The relaxation time scale adapts to the non-constant thickness of the mixed layer by scaling linearly from 30 days for $50 \mathrm{~m}$ thickness to longer times for a thicker mixed layer. The simulation used
OSD

$10,555-579,2013$

Salt transport in the Irminger Current

A. Born et al.

\section{Title Page}

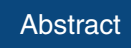

Introduction

Conclusions

References

Tables

Figures

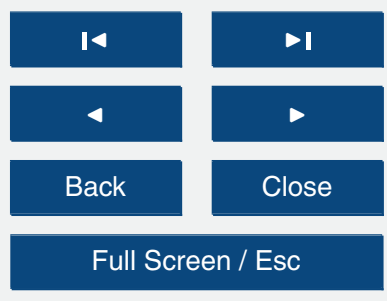

Printer-friendly Version

Interactive Discussion 
here has been studied extensively in Hátún et al. $(2005 a, b)$ and was found to represent hydrological records realistically.

The ocean component of CCSM4 is a z-coordinate rigid-lid model that employs a curvilinear grid with poles over Antarctica and Greenland (Danabasoglu et al., 5 2012a). This increases the nominal resolution of $1^{\circ}$ to approximately $50 \mathrm{~km}$ in the subpolar North Atlantic. The vertical is discretized with 60 levels of uniform $10 \mathrm{~m}$ thickness in the upper $160 \mathrm{~m}$ and increasing to $250 \mathrm{~m}$ at a depth of $3500 \mathrm{~m}$. Several parameterizations of subgrid processes improve the simulation of the subpolar North Atlantic, notably a near-surface eddy flux parameterization (Danabasoglu et al., 2008), a sub-

10 mesoscale mixing parameterization (Fox-Kemper et al., 2008b,a) and an improved representation of density-driven bottom flows across the Greenland-Scotland Ridge (Danabasoglu et al., 2010). The model ocean is coupled without flux adjustments to a finite volume atmosphere model of $1^{\circ}$ resolution and 26 vertical levels (Neale et al., 2013) and a comprehensive sea ice model (Hunke and Lipscomb, 2008; Holland et al., 15 2012). In contrast to MICOM, CCSM4 runs freely without relaxation to observed or reconstructed climatological fields. External forcing follows the Paleoclimate Modelling Intercomparison Project Phase III (PMIP3) protocol (Schmidt et al., 2011). The principal changes are variations in total solar irradiance prescribed using reconstructions by Vieira and Solanki (2010) and Lean et al. (2005), and the effect of explosive volcanic eruptions included by an estimate of the stratospheric sulfur aerosol distribution and optical thickness (Gao et al., 2008). A detailed description of this simulation is found in Landrum et al. (2013).

\section{Salinity and salt transport in the subpolar gyre}

\subsection{MICOM - last decades}

25 For the analysis of MICOM, we follow Hátún et al. (2005b) in order to investigate the effect of known hydrographic changes on salt transport. Therefore, EOFs have been
OSD

$10,555-579,2013$

Salt transport in the Irminger Current

A. Born et al.

\section{Title Page}

Abstract Introduction

Conclusions References

Tables Figures

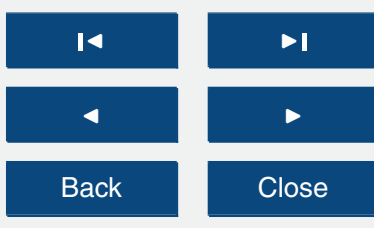

Full Screen / Esc

Printer-friendly Version

Interactive Discussion 
calculated from the sea surface height of the subpolar North Atlantic to quantify variations in the SPG. Supplementing Hátún et al. (2005b) we extend the analysis by ten years to the entire simulation period starting at 1950. This does not change the shape of the first two EOFs but their order. The formerly dominant EOF, that was found to 5 resemble the "gyre mode" of Häkkinen and Rhines (2004), corresponds to the second EOF (EOF2) for the full length of the simulation with $18.9 \%$ explained variance. The first EOF (EOF1) explains $27.3 \%$ of the simulated variance. To visualize the difference, composites of the depth integrated stream function are defined as greater and smaller than one standard deviation of the time series (principal components, PC) associated 10 with the first two EOFs (Fig. 1). EOF2 does not represent a uniform circulation change in the SPG, but rather a localized recirculation south of Iceland in combination with a relocation of the SPG/STG front. In contrast, the anomalous circulation associated with the dominant sea surface height EOF1 appears to be a better representation of variations that involve the entire SPG. Interestingly, the anomalous circulation related 15 to EOF1 resembles sea surface height anomalies associated with continuously positive North Atlantic Oscillation index (NAO) forcing in a regional version of the NEMO model, with maxima in the Labrador Sea and the Irminger Basin (Herbaut and Houssais, 2009). EOF2 anomalies in MICOM, focused in the northeastern SPG, are not unlike the circulation anomalies caused by continuously positive NAO wind stress forcing (neutral buoyancy fluxes) in NEMO.

Both EOFs are used to calculate composites of salinity and salt transport in the subpolar basin, for the variable-depth mixed layer (Fig. 2). The PC2 composite of sea surface salinity, equivalent of the "gyre mode" of Hátún et al. (2005b), shows the expected freshening with an anomalously positive index (Fig. 2c). It is the result of the relatively small recirculation in the northeastern corner of the SPG (Fig. 1b). A freshening is not observed with a more general strengthening of the SPG, the composite of PC1 (Fig. 2a). Here, salinity anomalies are mostly found in the path of the North Atlantic current but do not propagate into the SPG. Note, however, that the composites
OSD

$10,555-579,2013$

Salt transport in the Irminger Current

A. Born et al.

\section{Title Page}

Abstract Introduction

Conclusions References

Tables Figures

14

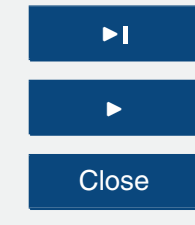

Back 
are based on relatively short time series and might therefore be contaminated by transient signals such as meanders of the North Atlantic Current.

Waters from the eastern subpolar North Atlantic are transported westward with the Irminger Current and lower salinities are seen along its path in the PC2 composite. 5 However, a freshening of the western basin does not follow. The stronger circulation not only reduces salinities in the source region of the Irminger Current but also increases its volume transport. With respect to salt transport, the more intense flow overcompensates the decrease in salinity (Fig. 2b, d).

Simulated variations associated with sea surface height EOF2 in MICOM are a good 10 representation of circulation changes during the second half of the last century and in particular the mid 1990s (Hátún et al., 2005a,b). We will now generalize the above findings with observational estimates for volume flux and salinity variations of the same period. Changes in salt transport depend both on changes in volume transport and changes in the salinity of the advected water masses. This is formalized as

$\Delta F=\Delta(S \cdot V) \cong V \cdot \Delta S+S \cdot \Delta V$

where the first term represents changes in salt transport $\Delta F$ due to variations in salinity $\Delta S$, scaled by the time average volume transport $V$. The second term denotes changes in volume transport $\Delta V$ scaled by the average salinity $S$. Terms of higher or$\operatorname{der}(\Delta S \cdot \Delta V)$ are usually small and have been neglected here. Approximate numeric values for recent decades are obtained from the literature. The average salinity of the Irminger Current is approximately $S=35$ psu and peak-to-peak near-surface variations are smaller than $\Delta S=0.1$ psu (Hátún et al., 2005b; Häkkinen et al., 2011, Fig. 2). Estimates of volume transport are less well constrained as they depend on the definition of the Irminger Current by density, salinity or depth contours. To be consistent, the estimass corresponding to the observed salinity variations at the near surface. Hence, we employ estimates by Våge et al. (2011) for the northward transport along the western flank of the Reykjanes Ridge, in the upper $500 \mathrm{~m}: V=7 \mathrm{~Sv}, \Delta V=3 \mathrm{~Sv}$.

OSD

$10,555-579,2013$

Salt transport in the Irminger Current

A. Born et al.

\section{Title Page}

Abstract Introduction

Conclusions References

Tables Figures

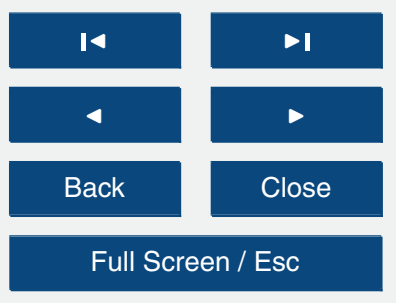

Printer-friendly Version

Interactive Discussion 
$R=\frac{S \cdot \Delta V}{V \cdot \Delta S}=150$

OSD

$10,555-579,2013$

Salinity variations are negligible for the salt transport anomalies in the presence of accompanying changes in volume transport. Equation (2) allows for an intuitive explana5 tion in the form $R=(\Delta V / V) \cdot(\Delta S / S)^{-1}$, meaning that changes in salt transport depend on relative, not absolute, variations in salinity and volume transport, that is normalized by their respective time averages. This demonstrates the robustness of this result, because independent of the exact measurement of volume transport, the relative changes in salinity $\Delta S / S$ will always be small.

10 3.2 Comparison of MICOM and CCSM4 - the last millennium

The simulation with MICOM is a good representation of the second half of the last century but too short to derive more general conclusions on salt advection in the SPG. We thus employ a simulation with CCSM4 of the preindustrial millennium. This approach naturally leads to the interesting question about the similarities of the two models with 15 considerably different characteristics.

The EOFs of sea surface height are different in both models. The first two EOFs of CCSM4 for approximately the same region as chosen in MICOM above find one important center of action in the path of the North Atlantic Current (not shown), unlike MICOM. While this result suggests a difference in the simulated variability between the models or indeed between interdecadal and centennial time scales no reliable conclusions can be drawn from this analysis. EOFs are highly sensitive to the chosen domain which necessarily differs in the two models, e.g. due to different resolutions of the coast lines and numerical grids. To compare anomalous fields of both models, we define a more robust metric that approximates more closely the physical process to be investigated, and that has been used in previous model comparisons (Born et al., 2012). The SPG index $S P G_{A V E}$ is the average of the depth-integrated stream function 562
Salt transport in the Irminger Current

A. Born et al.

\section{Title Page}

Abstract Introduction

Conclusions References

Tables Figures

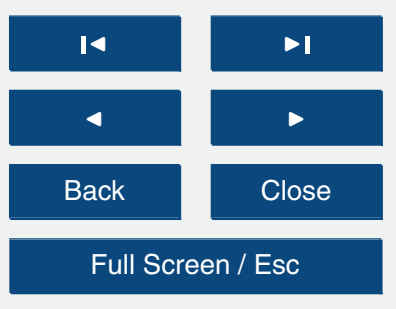

Printer-friendly Version

Interactive Discussion 
in the subpolar North Atlantic $\left(60^{\circ} \mathrm{W}-5^{\circ} \mathrm{W}, 48^{\circ} \mathrm{N}-65^{\circ} \mathrm{N}\right.$, see Fig. 3b). As before, composites are defined as \pm 1 standard deviation.

The time average circulation of the SPG and patterns of variability are similar in both models. The anomalous circulation is concentrated in the western basin and extends 5 to the south, shifting the North Atlantic Current (Fig. 3a, b). As a consequence of the enhanced volume transport in the SPG, salt transport increases around the northern and western rim of the gyre. Absolute values of salt transport can not be compared between the two models because of its different vertical extent. For MICOM, salt transport is integrated over the mixed layer which is several hundred meters thick in parts of the advection path. In CCSM4, the salt transport is calculated for the upper $100 \mathrm{~m}$. Also, one standard deviation of the SPG ${ }_{A V E}$ index is more than twice as large in MICOM $(1.56 \mathrm{~Sv})$ than in CCSM4 $(0.76 \mathrm{~Sv})$. Salt transport appears to be more diffuse in CCSM4, partly due to the lower lateral resolution but also because the composites are calculated from 1000 model years with many slightly different looking occurrences of 15 high and low transports.

Sea surface salinities in the western basin increase by up to 0.5 psu in CCSM4. Accumulation of salt is not as clear in MICOM and limited mostly to the boundary currents (Fig. 3e, f). The vertical extent of salinity anomalies is analyzed for two representative sections (Fig. 4). Salinity anomalies are limited mostly to the upper $100 \mathrm{~m}$ and barely detectable below $200 \mathrm{~m}$ in both sections. Anomalous flow velocities across the Reykjanes Ridge are also strongest near the surface but can be observed down to a depth of $1000 \mathrm{~m}$. In the Labrador Sea, anomalous velocities are strong at almost all depth levels, showing the barotropic nature of the SPG circulation changes.

To investigate how the observed anomaly in surface salinity relates to the anoma25 lous salt transport, we analyze the divergence of the salt transport and its components in CCSM4 (Fig. 5). As before, the analysis will focus on the upper $100 \mathrm{~m}$ where the increase in salinity is most evident and that has the strongest impact on deep convection. However, unlike before, volume transport is reduced to velocity because the divergence of $S \cdot U$ yields the more accessible unit of salinity change per unit time (psu ${ }^{-1}$ ).
OSD

$10,555-579,2013$

Salt transport in the Irminger Current

A. Born et al.

\section{Title Page}

Abstract Introduction

Conclusions References

Tables Figures

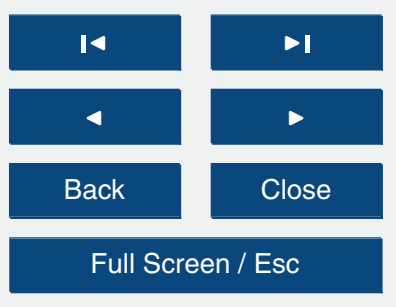

Printer-friendly Version

Interactive Discussion 
Converging salt transport explains only part of the salinity anomaly (Fig. 5a), while a greater contribution to the salinity anomaly appears to result from a stronger doming of isopycnals and therewith enhanced upward mixing of saline water from deeper layers (Fig. 5b). This is consistent with the lack of higher surface salinities in the isopycnal 5 model MICOM where shoaling isopycnals make the surface layer thinner but do not change its tracer composition.

However, the enhanced salt transport converges in a region of deep convection and thereby increases its effectiveness (not shown). Stronger deep convection and loss of heat in turn lifts the isopycnals and mixes saline water upward. So, while not a direct 10 consequence, the observed increase in surface salinity is indirectly caused by the enhanced salt transport. Changes in the East Greenland Current and Arctic freshwater export are negligible in both models (Fig. 3a, b). Air-sea exchanges play a minor role (Fig. 6).

The divergence in salt transport $\Delta(S \cdot U)$ is almost entirely the result of changes in 15

volume transport $S \Delta U$ (Fig. 5c). Changes in salinity $U \Delta S$ are negligible (Fig. $5 \mathrm{~d}$ ). The volume transport is further divided into its advective component $U_{\text {adv }}$ and the parameterized, subgrid part $U_{\text {sg }}$, representing eddy mixing. The corresponding divergences show that the transport of salt from the eastern to the western basin is primarily due to advection, while the convergence in the deep convection region is a result of subgrid eddy transports (Fig. 5e, f).

The strengthening of the SPG from the late 1980s and subsequent weakening after 1995 is not reflected in corresponding salinity changes in observations downstream in the Labrador Sea (Yashayaev, 2007), apparently contradicting our findings. Indeed, the salinity composites presented here also do not show a notable increase in salinity

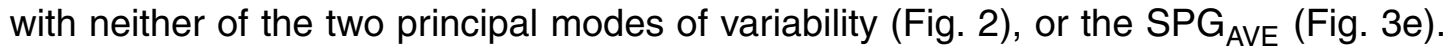
This can be attributed to the salinity changes being relatively small compared to other influences and the observational record being too short to reliably separate circulationrelated signals from others.
OSD

$10,555-579,2013$

Salt transport in the Irminger Current

A. Born et al.

\section{Title Page}

Abstract Introduction

Conclusions References

Tables Figures

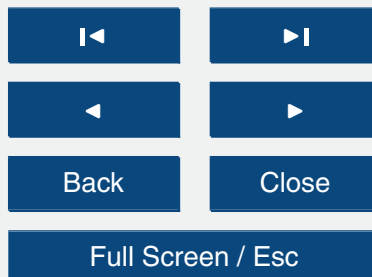

Printer-friendly Version

Interactive Discussion 
Sea surface salinity in the western basin (see black rectangle in Fig. 3f) and the (negative) $S P G_{A V E}$ index show a significant (anti-) correlation in CCSM4 ( $r=-0.5$, Fig. 7). To remove information from periods longer than the satellite altimetry record that is commonly used to estimate the SPG circulation strength $(\sim 30 \mathrm{yr})$, both time 5 series are high-pass filtered with a cut-off at $30 \mathrm{yr}$. The resulting cross-correlation is below the $95 \%$ significance threshold $(r=-0.16)$ and therefore indistinguishable from a signal of unrelated origin. This suggests that observations of sea surface salinity are too short to discern whether their origin is related to enhanced salt transport in the SPG. The significance threshold has been estimated assuming SPG variations of $20 \mathrm{yr}$ 10 period, which gives 50 degrees of freedom for the $1000-y r$ simulation.

\section{Summary and conclusions}

Salt transport in the upper layers of the SPG and the connection of the eastern and western subpolar North Atlantic basin have repeatedly been described as important parts of climate variability (Delworth et al., 1993; Yoshimori et al., 2010; Lozier, 2010; 15 Born and Mignot, 2011; Kwon and Frankignoul, 2012; Langehaug et al., 2012; Danabasoglu et al., 2012b). Our results suggest that this connection cannot be simplified to the mere communication of existing anomalies from east to west but that the variable transport itself creates salinity anomalies.

We investigated the transport and convergence of salt in two general circulation mod20

els with very different characteristics, a regional isopycnal ocean model forced by observations for the second half of the last century (1950-2002 AD, MICOM), and a global coupled climate model with a z-coordinate ocean driven by external forcing for the preindustrial millennium (850-1850 AD, CCSM4). While the regional model is primarily used to ensure consistency with recent observations, CCSM4 provides time series long enough for more general conclusions. Indeed, dominant variations in the surface circulation and associated surface salinity fingerprints of recent decades (Hátún et al., 2005b) differ from long-term changes. Consequently, analogies with recent decades
OSD

$10,555-579,2013$

Salt transport in the Irminger Current

A. Born et al.

\section{Title Page}

Abstract Introduction

Conclusions References

Tables Figures

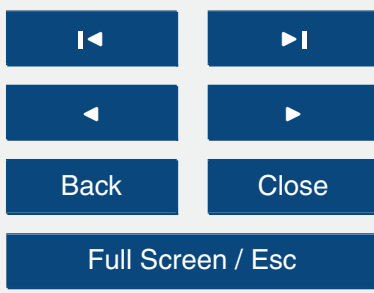

Printer-friendly Version

Interactive Discussion 
provide little constraint for reconstructions of past SPG variability (e.g. Thornalley et al., 2009).

Both models agree that a stronger SPG transports more salt along its northern rim as a result of an increased volume transport. Anomalous salinities in the eastern subpolar 5 North Atlantic are negligible as the effect of typical changes is two orders of magnitude smaller than for typical variations in volume transport. This basic result is indeed easily estimated from observational data and is consistent with earlier works that describe the importance of advection for salinities of the Iceland Basin (Herbaut and Houssais, 2009) and the Irminger Basin (Desprès et al., 2011).

10 The analysis of surface salt convergence adds important detail on the respective roles of explicit advective and parameterized subgrid transports. While advection transports salt over relatively large distances from the eastern into the western basin, it does not converge and therefore not increase surface salinity in the region. It is the subgrid transports, parameterized eddies, that accumulate salt in the western basin, consistent with observations (Lilly et al., 1999; Lilly and Rhines, 2002; Prater, 2002) and eddy-resolving numerical modeling (Spall, 2004). Previous work with CCSM4 found the convergence of subgrid transports to correlate with surface density in the deep convection region, causing changes in the AMOC (Danabasoglu et al., 2012b). We extend these findings and specify that these changes are linked to variations in the SPG 20 and advective salt transport from east to west.

This understanding implies a positive feedback mechanism: enhanced salt transport into the western basin favors deep convection. Deep convection cools the water column and makes it more dense which strengthens the cyclonic flow of lighter waters around it. This intensification of the SPG then carries more salt again. If less salt was 25 transported in a stronger SPG as a result of decreasing salinities in the eastern basin, the feedback would be negative and climate variability of the North Atlantic would arguably be of smaller amplitude (Mengel et al., 2012). This positive advective-convective feedback has been discussed in climate models (Levermann and Born, 2007; Born and Mignot, 2011; Born et al., 2012) and has successfully been used for the explanation
OSD

10, 555-579, 2013

Salt transport in the Irminger Current

A. Born et al.

\section{Title Page}

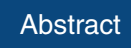

Introduction

Conclusions

References

Tables

Figures

14

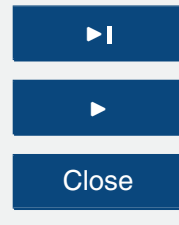

Back 
of paleoclimate reconstructions (Born and Levermann, 2010; Born et al., 2011; Irvali et al., 2012).

These findings strongly reinforce the importance of the SPG for large-scale circulation changes. The advection of far-field anomalies into the western subpolar North 5 Atlantic is of little relevance if accompanied by a change in the SPG circulation, which in the case of decadal AMOC variability is observed in virtually all coupled climate models (Yoshimori et al., 2010, Table 1). However, this does not preclude the modulation by centennial-scale advection of salt anomalies from afar that might be superimposed on the decadal SPG signal (e.g. Delworth and Zeng, 2012).

10 Acknowledgements. The simulation with CCSM4 was carried out on CISL compute and storage resources. MICOM simulations were supported by the Norwegian Supercomputer Committee. A. B. is supported by the European Commission under the Marie Curie Intra-European Fellowship ECLIPS (PIEF-GA-2011-300544) and the "National Centre for Excellence in Research: Climate" of the Swiss National Science Foundation.

\section{References}

Bentsen, $M$. and Drange, $H$.: Parameterizing surface fluxes in ocean models using the NCEP/NCAR reanalysis data, in: RegClim General Technical Report No. 4, 149-158, Norwegian Institute for Air Research, Kjeller, 2000. 558

Bentsen, M., Drange, H., Furevik, T., and Zhou, T.: Simulated variability of the Atlantic meridional overturning circulation, Clim. Dynam., 22, 701-720, doi:10.1007/s00382-004-0397-x, 2004. 558

Born, A. and Levermann, A.: The $8.2 \mathrm{ka}$ event: abrupt transition of the subpolar gyre toward a modern North Atlantic circulation, Geochem. Geophy. Geosy., 11, Q06011, doi:10.1029/2009GC003024, 2010. 567

Born, A. and Mignot, J.: Dynamics of decadal variability in the Atlantic subpolar gyre: a stochastically forced oscillator, Clim. Dynam., 39, 461-474, doi:10.1007/s00382-011-1180-4, 2011. $556,565,566$
OSD

$10,555-579,2013$

Salt transport in the Irminger Current

A. Born et al.

\section{Title Page}

Abstract

Introduction

Conclusions

References

Tables

Figures

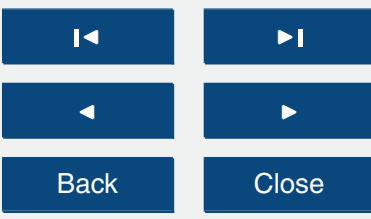

Full Screen / Esc

Printer-friendly Version

Interactive Discussion 
Born, A., Nisancioglu, K. H., and Risebrobakken, B.: Late Eemian warming in the Nordic Seas as seen in proxy data and climate models, Paleoceanography, 26, PA2207, doi:10.1029/2010PA002027, 2011. 567

Born, A., Stocker, T. F., Raible, C. C., and Levermann, A.: Is the Atlantic subpolar gyre bistable 5 in comprehensive coupled climate models?, Clim. Dynam., doi:10.1007/s00382-012-1525-7, 2012. 562, 566

Danabasoglu, G., Ferrari, R., and McWilliams, J. C.: Sensitivity of an ocean general circulation model to a parameterization of near-surface eddy fluxes, J. Climate, 21, 1192-1208, doi:10.1175/2007JCLI1508.1, 2008. 559

10 Danabasoglu, G., Large, W. G., and Briegleb, B. P.: Climate impacts of parameterized Nordic Sea overflows, J. Geophys. Res., 115, C11005, doi:10.1029/2010JC006243, 2010. 559

Danabasoglu, G., Bates, S., Briegleb, B. P., Jayne, S. R., Jochum, M., Large, W. G., Peacock, S., and Yeager, S. G.: The CCSM4 ocean component, J. Climate, 25, 1361-1389, doi:10.1175/JCLI-D-11-00091.1, 2012a. 559

Danabasoglu, G., Yeager, S. G., Kwon, Y.-O., Tribbia, J. J., Phillips, A. S., and Hurrell, J. W.: Variability of the Atlantic meridional overturning circulation in CCSM4, J. Climate, 25, 51535172, doi:10.1175/JCLI-D-11-00463.1, 2012b. 565, 566

Delworth, T. L. and Zeng, F.: Multicentennial variability of the Atlantic meridional overturning circulation and its climatic influence in a 4000 year simulation of the GFDL CM2.1 climate model, Geophys. Res. Lett., 39, L13702, doi:10.1029/2012GL052107, 2012. 567

Delworth, T. L., Manabe, S., and Stouffer, R. J.: Interdecadal variations of the thermohaline circulation in a coupled ocean-atmosphere model, J. Climate, 6, 1993-2011, 1993. 556, 565

Desprès, A., Reverdin, G., and D'Ovidio, F.: Mechanisms and spatial variability of meso scale frontogenesis in the northwestern subpolar gyre, Ocean Modell., 39, 97-113, 2011. 566

Eden, C. and Willebrand, J.: Mechanism of interannual to decadal variability of the North Atlantic circulation, J. Climate, 14, 2266-2280, 2001. 556

Eldevik, T., Straneo, F., Sandø, A. B., and Furevik, T.: Ventilation and spreading of Greenland Sea Water, in: The Nordic Seas, an Integrated Perspective, edited by: Drange, H., Dokken, T. M., Furevik, T., Gerdes, R., and Berger, W., AGU Geophysical Monograph Series no. 158, Washington DC, 89-103, 2005. 558

Fox-Kemper, B., Danabasoglu, G., Ferrari, R., and Hallberg, R. W.: Parameterizing submesoscale physics in global climate models, CLIVAR Exchanges, 13, 3-5, 2008a. 559
OSD

$10,555-579,2013$

Salt transport in the Irminger Current

A. Born et al.

\section{Title Page}

Abstract

Introduction

Conclusions References

Tables

Figures

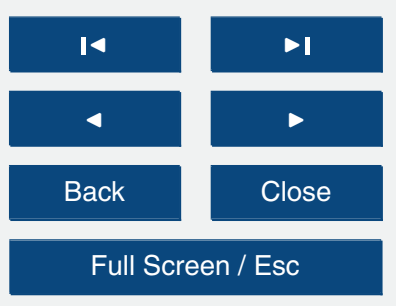

Printer-friendly Version

Interactive Discussion 
Fox-Kemper, B., Ferrari, R., and Hallberg, R.: Parameterization of mixed layer eddies. Part I: Theory and diagnosis, J. Phys. Oceanogr., 38, 1145-1165, doi:10.1175/2007JPO3792.1, 2008b. 559

Furevik, T., Bentsen, M., Drange, H., Johannessen, J. A., and Korablev, A.: Temporal and spatial variability of the sea surface salinity in the Nordic Seas, J. Geophys. Res., 107, 8009, doi:10.1029/2001JC001118, 2002. 558

Gao, C., Robock, A., and Ammann, C.: Volcanic forcing of climate over the last 1500 years: an improved ice-core based index for climate models, J. Geophys. Res., 113, D2311, doi:10.1029/2008JD010239, 2008. 559

10 Gent, P. R., Danabasoglu, G., Donner, L., Holland, M., Hunke, E., Jayne, S., Lawrence, D., Neale, R., Rasch, P., Vertenstein, M., Worley, P., Yang, Z.-L., and Zhang, M.: The community climate system model version 4, J. Climate, 24, 4973-4991, 2011. 558

Häkkinen, S. and Rhines, P. B.: Decline of subpolar North Atlantic circulation during the 1990s, Science, 304, 555-559, 2004. 556, 560

15 Häkkinen, S. and Rhines, P. B.: Shifting surface currents in the northern North Atlantic Ocean, J. Geophys. Res., 114, C04005, doi:10.1029/2008JC004883, 2009. 557

Häkkinen, S., Rhines, P. B., and Worthen, D. L.: Warm and saline events embedded in the meridional circulation of the northern North Atlantic, J. Geophys. Res., 116, C03006, doi:10.1029/2010JC006275, 2011. 557, 561

20 Hátún, H., Sandø, A. B., Drange, H., and Bentsen, M.: Seasonal to Decadal Temperature Variations in the Faroe-Shetland Inflow Waters, in: The Nordic Seas, an Integrated Perspective,edited by: Drange, H., Dokken, T. M., Furevik, T., Gerdes, R., and Berger, W. H., AGU Geophysical Monograph Series no. 158, Washington DC, 239-250, 2005a. 558, 559, 561

Hátún, H., Sandø, A. B., Drange, H., Hansen, B., and Valdimarsson, H.: Influence of the Atlantic subpolar gyre on the thermohaline circulation, Science, 309, 1841-1844, 2005b. 557, 558, $559,560,561,565$

Herbaut, C. and Houssais, M.-N.: Response of the eastern North Atlantic subpolar gyre to the North Atlantic oscillation, Geophys. Res. Lett., 36, L17607, doi:10.1029/2009GL039090, 2009. 560, 566

30 Holland, M. M., Bailey, D. A., Briegleb, B. P., Light, B., and Hunke, E.: Improved sea ice shortwave radiation physics in CCSM4: the impact of melt ponds and aerosols on Arctic sea ice, J. Climate, 25, 1413-1430, doi:10.1175/JCLI-D-11-00078.1, 2012. 559
OSD

10, 555-579, 2013

Salt transport in the Irminger Current

A. Born et al.

\section{Title Page}

Abstract

Introduction

Conclusions References

Tables

Figures

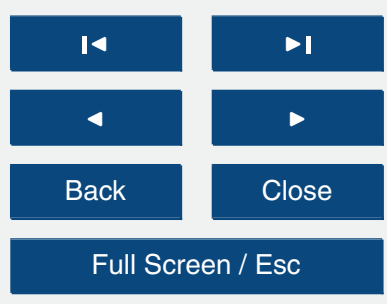

Printer-friendly Version

Interactive Discussion 
Hunke, E. C. and Lipscomb, W. H.: CICE: the Los Alamos sea ice model user's manual, version 4, Tech. rep., 2008. 559

Irvali, N., Ninneman, U. S., Galaasen, E. V., Rosenthal, Y., Kroon, D., Oppo, D. W., Kleiven, H. F., Darling, K. F., and Kissel, C.: Rapid switches in subpolar North Atlantic hy5 drography and climate during the Last Interglacial (MIS 5e), Paleoceanography, 27, PA2207, doi:10.1029/2011PA002244, 2012. 567

Kistler, R., Kalnay, E., Collins, W., Saha, S., White, G., Wollen, J., Chelliah, M., Ebisuzaki, W., Kanamitsu, M., Kousky, V., den Dool, H. V., Jenne, R., and Fiorini, M.: The NCEP-NCAR 50 -Year reanalysis, monthly means, CD-ROM and documentation, B. Am. Meteorol. Soc., $10 \quad 82,247-268,2001.558$

Kwon, Y.-O. and Frankignoul, C.: Stochastically-driven multidecadal variability of the Atlantic meridional overturning circulation in CCSM3, Clim. Dynam., 38, 859-876, doi:10.1007/s00382-011-1040-2, 2012. 565

Landrum, L., Otto-Bliesner, B. L., Conley, A., Lawrence, P., Rosenbloom, N., and Teng, H.: 15 Last millennium climate and its variability in CCSM4, J. Climate, 26, 1085-1111, doi:10.1175/JCLI-D-11-00326.1, 2013. 559

Langehaug, H., Medhaug, I., Eldevik, T., and Otterå, O. H.: Arctic/Atlantic exchanges via the subpolar gyre, J. Climate, 25, 2421-2439, doi:10.1175/JCLI-D-11-00085.1, 2012. 565

Lean, J., Rottman, G., Harder, J., and Kopp, G.: SORCE contributions to new understanding of global change and solar variability, Solar Phys., 230, 27-53, 2005. 559

Levermann, A. and Born, A.: Bistability of the Atlantic subpolar gyre in a coarse-resolution model, Geophys. Res. Lett., 34, L24605, doi:10.1029/2007GL031732, 2007. 566

Levitus, S. and Boyer, T. P.: World Ocean Atlas 1994 Volume 4: Temperature, NOAA Atlas NESDIS 4, 1994. 558

25 Levitus, S., Burgett, R., and Boyer, T. P.: (1994), World Ocean Atlas 1994 Volume 3: Salinity, NOAA Atlas NESDIS 3, 1994. 558

Lilly, J. M. and Rhines, P. B.: Coherent Eddies in the Labrador Sea observed from a mooring, J. Phys. Oceanogr., 32, 585-598, 2002. 566

Lilly, J. M., Rhines, P. B., Visbeck, M., Davis, R., Lazier, J. R. N., Schott, F., and Farmer, D.: 30 Observing deep convection in the Labrador Sea during winter 1994/95, J. Phys. Oceanogr., 29, 2065-2098, 1999. 566

Lozier, S.: Deconstructing the Conveyor Belt, Science, 328, 1507-1511, 2010. 565

OSD

10, 555-579, 2013

Salt transport in the Irminger Current

A. Born et al.

\section{Title Page}

Abstract Introduction

Conclusions

References

Tables

Figures

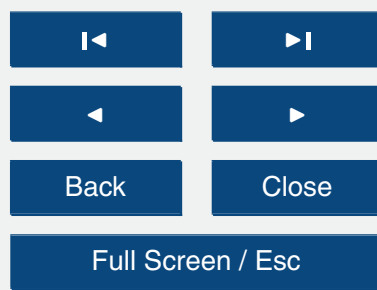

Printer-friendly Version

Interactive Discussion 
Mauritzen, C., Hjøllo, S. S., and Sandø, A. B.: Passive tracers and active dynamics: a model study of hydrography and circulation in the northern North Atlantic, J. Geophys. Res., 111, C08014, doi:10.1029/2005JC003252, 2006. 558

Mengel, M., Levermann, A., Schleussner, C.-F., and Born, A.: Enhanced Atlantic subpolar gyre 5 variability through baroclinic threshold in a coarse resolution model, Earth Syst. Dynam., 3, 189-197, doi:10.5194/esd-3-189-2012, 2012. 566

Neale, R. B., Richter, J., Park, S., Lauritzen, P. H., Vavrus, S. J., Rasch, P. J., and Zhang, M.: The mean climate of the Community Atmosphere Model (CAM4) in forced SST and fully coupled experiments, J. Climate, in press, doi:10.1175/JCLI-D-12-00236.1, 2013. 559

10 Nilsen, J. E., Gao, Y., Drange, H., Furevik, T., and Bentsen, M.: Simulated North Atlantic-Nordic Seas water mass exchanges in an isopycnic coordinate OGCM, Geophys. Res. Lett., 30, 1536, doi:10.1029/2002GL016597, 2003. 558

Prater, M. D.: Eddies in the Labrador Sea as observed by profiling RAFOS floats and remote sensing, J. Phys. Oceanogr., 32, 411-427, 2002. 566

Robson, J., Sutton, R., Lohmann, K., Smith, D., and Palmer, M. D.: Causes of the rapid warming of the North Atlantic ocean in the mid 1990s, J. Climate, 25, 4116-4134, doi:10.1175/JCLID-11-00443.1, 2012. 556

Sandø, A. B. and Furevik, T.: Relation between the wind stress curl in the North Atlantic and the Atlantic inflow to the Nordic Seas, J. Geophys. Res., 113, C06028, doi:10.1029/2007JC004236, 2008. 558

Schmidt, G. A., Jungclaus, J. H., Ammann, C. M., Bard, E., Braconnot, P., Crowley, T. J., Delaygue, G., Joos, F., Krivova, N. A., Muscheler, R., Otto-Bliesner, B. L., Pongratz, J., Shindell, D. T., Solanki, S. K., Steinhilber, F., and Vieira, L. E. A.: Climate forcing reconstructions for use in PMIP simulations of the last millennium (v1.0), Geosci. Model Dev., 4, 33-45, doi:10.5194/gmd-4-33-2011, 2011. 559

Spall, M. A.: Boundary currents and watermass transformation in marginal seas, J. Phys. Oceanogr., 34, 1197-1213, 2004. 566

Spall, M. A.: Low-frequency interaction between horizontal and overturning gyres in the ocean, Geophys. Res. Lett., 35, L18614, doi:10.1029/2008GL035206, 2008. 556

30 Thornalley, D. J. R., Elderfield, H., and McCave, I. N.: Holocene oscillations in temperature and salinity of the surface North Atlantic, Nature, 457, 711-714, 2009. 557, 566

Våge, K., Pickart, R. S., Sarafanov, A., Knutsen, Ø., Mercier, H., Lherminier, P., van Aken, H. M., Meincke, J., Quadfasel, D., and Bacon, S.: The Irminger Gyre: circulation, convection, and in-
OSD

$10,555-579,2013$

Salt transport in the Irminger Current

A. Born et al.

\section{Title Page}

Abstract

Introduction

Conclusions References

Tables

Figures

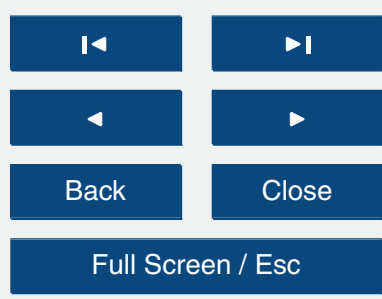

Printer-friendly Version

Interactive Discussion 
terannual variability, Deep-Sea Res. Pt. I, 58, 590-614, doi:10.1016/j.dsr.2011.03.001, 2011. 561

Vieira, L. E. A. and Solanki, S. K.: Evolution of the solar magnetic flux on time scales of years to millenia, Astron. Astrophys., 509, A100, doi:10.1051/0004-6361/200913276, 2010. 559

5 Yashayaev, I.: Hydrographic changes in the Labrador Sea, 1960-2005, Prog. Oceanogr., 73, 242-276, doi:10.1016/j.pocean.2007.04.015, 2007. 564

Yeager, S., Karspeck, A., Danabasoglu, G., Tribbia, J., and Teng, H.: A decadal prediction case study: late 20th century North Atlantic ocean heat content, J. Climate, 25, 5173-5189, doi:10.1175/JCLI-D-11-00595.1, 2012. 556

10 Yoshimori, M., Raible, C. C., Stocker, T. F., and Renold, M.: Simulated decadal oscillations of the Atlantic meridional overturning circulation in a cold climate state, Clim. Dynam., 34, 101-121, 2010. 556, 565, 567

\section{OSD}

10, 555-579, 2013

Salt transport in the Irminger Current
A. Born et al.

\section{Title Page}

Abstract

Introduction

Conclusions

References

Tables

Figures

14

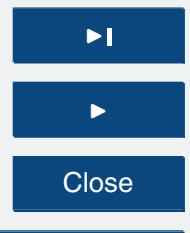

Full Screen / Esc

Printer-friendly Version

Interactive Discussion 

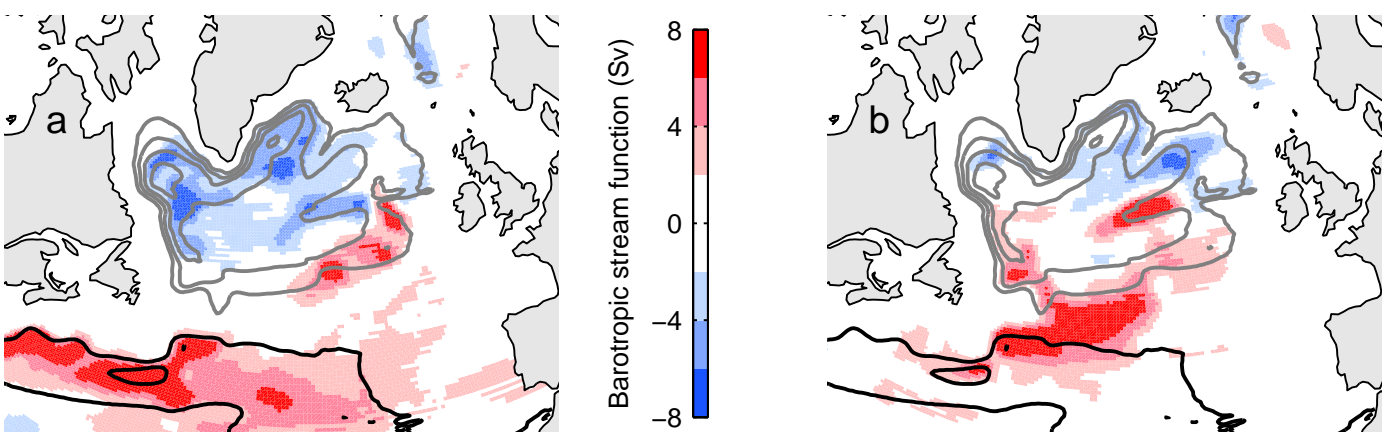

Fig. 1. Composite anomalies of the depth-integrated stream function of MICOM (colors), based on sea surface height PC1 (a) and PC2 (b). Contours show the time average stream function (spacing $10 \mathrm{~Sv}$, negative gray, zero omitted).
OSD

$10,555-579,2013$

Salt transport in the Irminger Current
A. Born et al.

Title Page

\section{Abstract}

Introduction

Conclusions

References

Tables

Figures

14

DI

4

Back

Full Screen / Esc

Printer-friendly Version

Interactive Discussion 

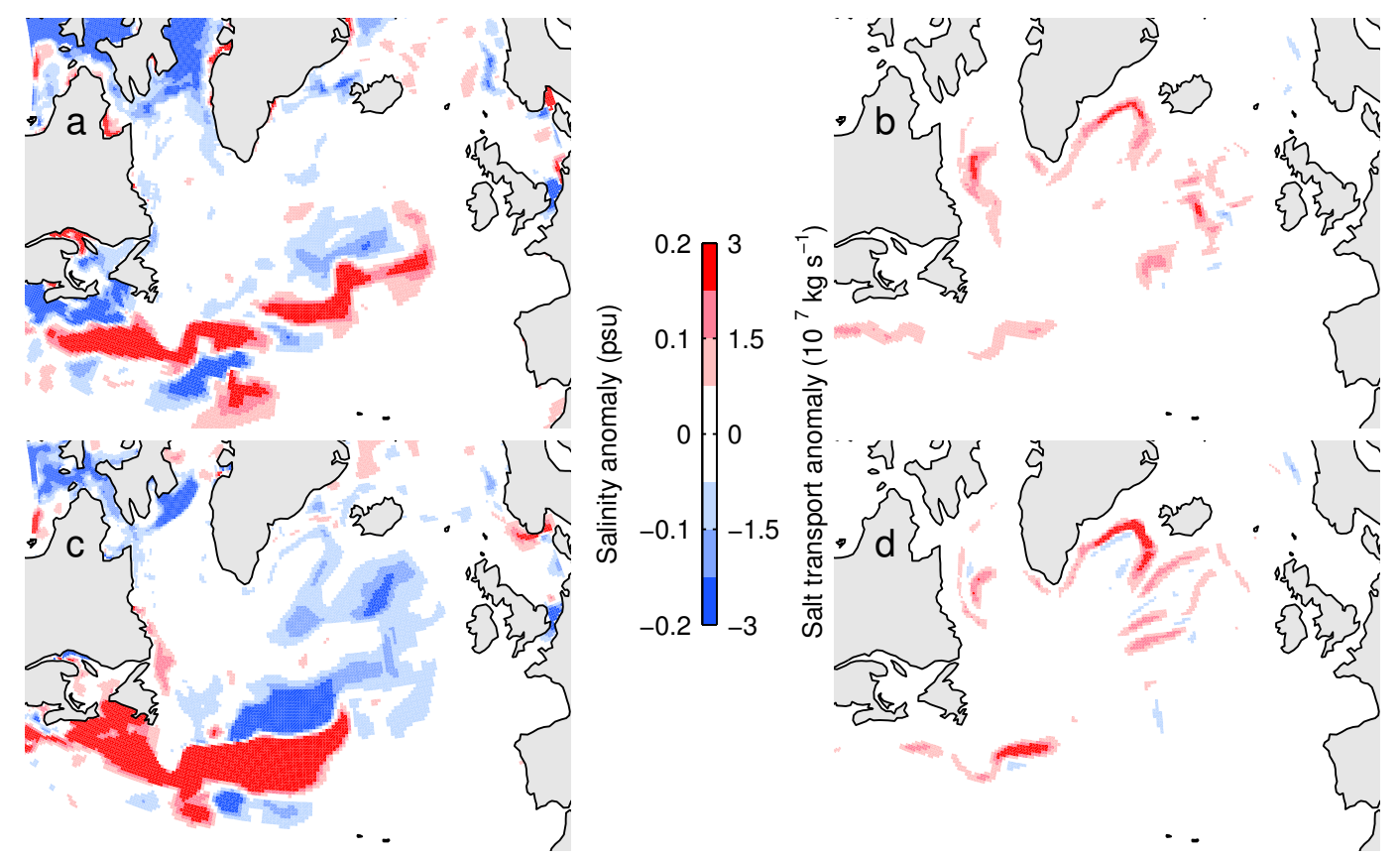

Fig. 2. Composite anomalies of surface salinity $(\mathbf{a}, \mathbf{c})$ and salt transport (b, d) in MICOM, based on sea surface height PC1 (upper) and PC2 (lower). Westward salt transport in the Irminger Current increases with a stronger circulation, irrespective of salinity change in the eastern source region.
OSD

$10,555-579,2013$

Salt transport in the Irminger Current
A. Born et al.

Title Page

\begin{tabular}{|c|c|}
\hline Abstract & Introduction \\
\hline Conclusions & References \\
\hline Tables & Figures \\
\hline & \\
\hline I & $\triangleright$ \\
\hline 4 & $\triangleright$ \\
\hline Back & Close \\
\hline Full Screen / Esc \\
\hline
\end{tabular}

Printer-friendly Version

Interactive Discussion 


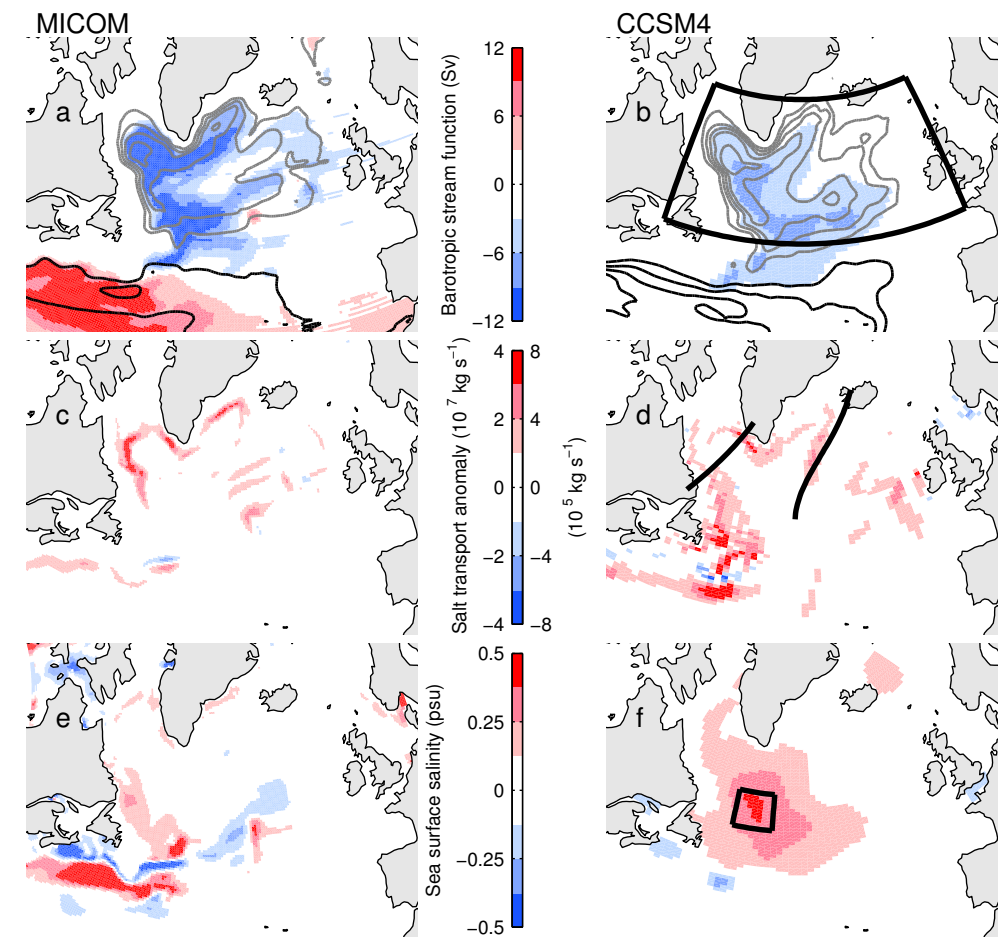

Fig. 3. Composite differences SPG $\mathrm{AVE}_{\mathrm{E}}$ strong-weak for MICOM (left column) and CCSM4 (right column); (a, b): depth-integrated stream function (colors). The time average stream function is shown as a reference (contours, $10 \mathrm{~Sv}$ spacing, negative gray, zero omitted); (c, d): salt transport in the mixed layer (MICOM) and the upper $100 \mathrm{~m}$ (CCSM4); (e, f): surface salinity. Models agree on the pattern of the simulated circulation anomaly and corresponding salt transport. The salinity anomaly in the western basin which is relatively weak in MICOM. The SPG ${ }_{\text {AVE }}$ index is defined as the average of the depth-integrated stream function in the black box in (b). The correlation of sea surface salinity inside the black rectangle in (f) and the SPG ${ }_{A V E}$ index is discussed in the main text. Black lines in (d) show sections used in Fig. 4.
OSD

$10,555-579,2013$

Salt transport in the Irminger Current

A. Born et al.

\section{Title Page}

\section{Abstract}

Introduction

Conclusions

References

Tables

Figures

14

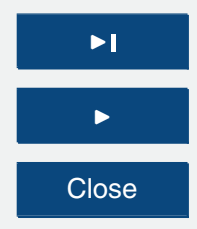

Back

Full Screen / Esc

Printer-friendly Version

Interactive Discussion 

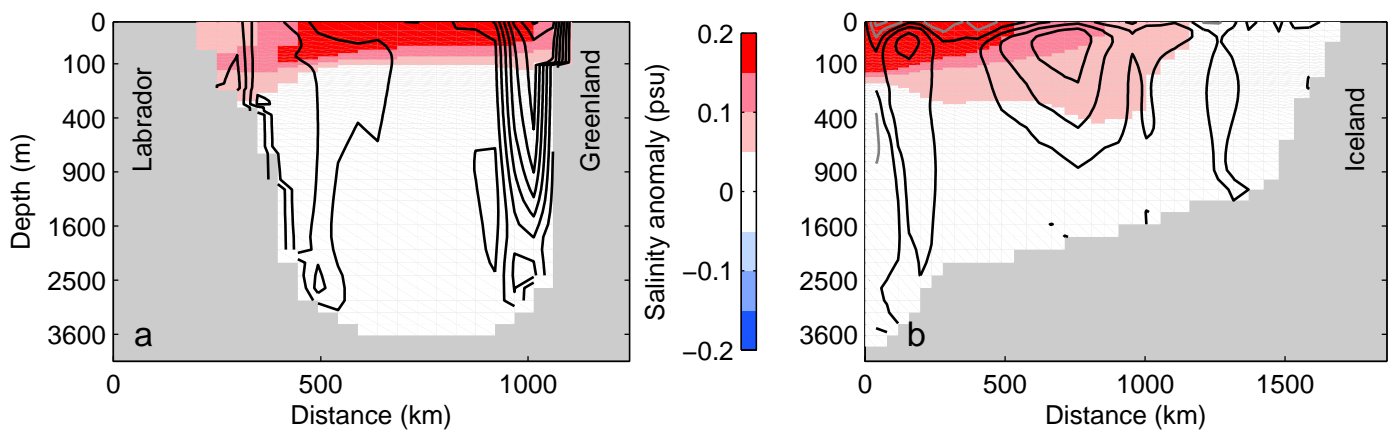

OSD

10, 555-579, 2013

Salt transport in the Irminger Current
A. Born et al.

Title Page

Abstract

Introduction

Conclusions

References

Tables

Figures

Fig. 4. Composite differences $S P G_{A V E}$ strong-weak of salinity (shading) and velocity (contours, spacing $0.5 \mathrm{~cm} \mathrm{~s}^{-1}$, negative gray) for CCSM4 for sections across the Labrador Sea (a) and along the Reykjanes Ridge (b). Locations of sections shown in Fig. 3d.

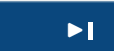

4

Back

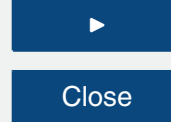

Full Screen / Esc

Printer-friendly Version

Interactive Discussion 


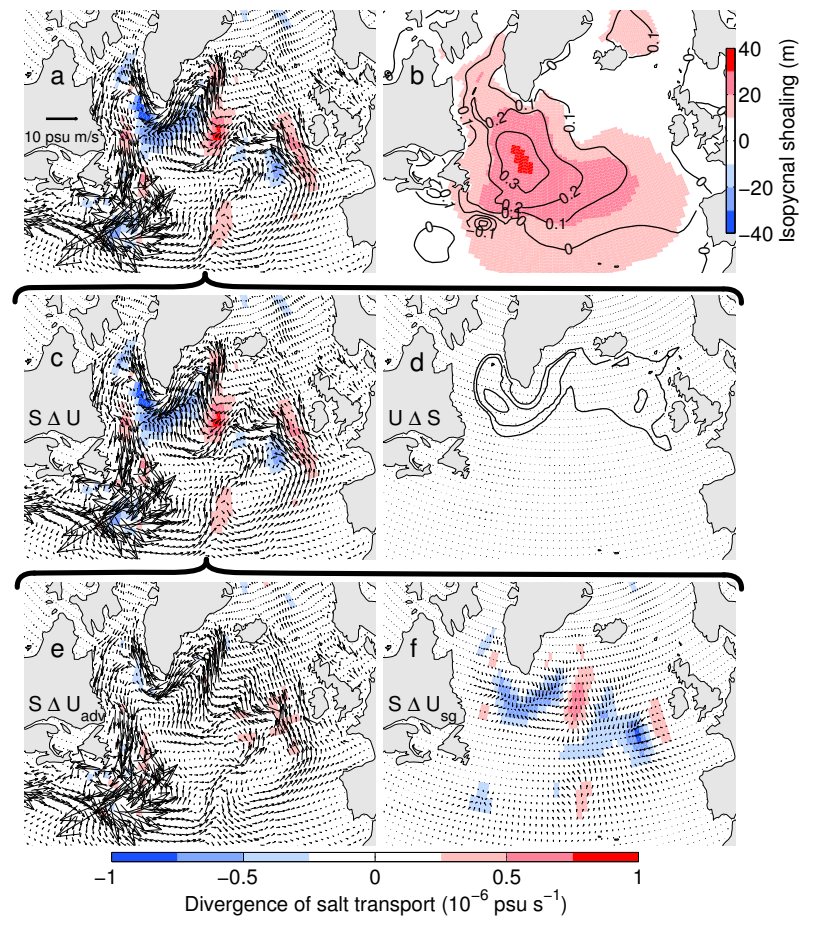

Fig. 5. (a) composite anomalous salt transport for strong-weak $S P G_{A V E}$ (arrows) and divergence thereof (colors) in CCSM4. (b) shoaling of isopycnals (color) and surface salinity anomaly (contours, in psu, see Fig. 3f) for strong-weak SPG ${ }_{A V E}$. (c-f) as (a) for components of salt transport. Contours in (d) represent time average March mixed layer depth (spacing $500 \mathrm{~m}$ ). Anomalous salt transport is dominated by variations in volume transport $(S \Delta U)$ that converge in the deep convection region (a, c). This convergence is mainly due to subgrid (sg) transports (f), while advection transports salt from the eastern to the western basin (e).

\section{OSD}

$10,555-579,2013$

Salt transport in the Irminger Current

A. Born et al.

\section{Title Page}

\section{Abstract}

Introduction

Conclusions

References

Tables

Figures
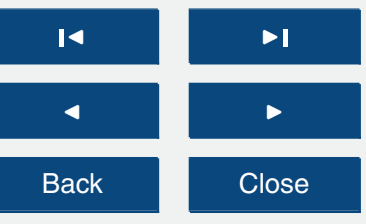

Full Screen / Esc

Printer-friendly Version

Interactive Discussion 


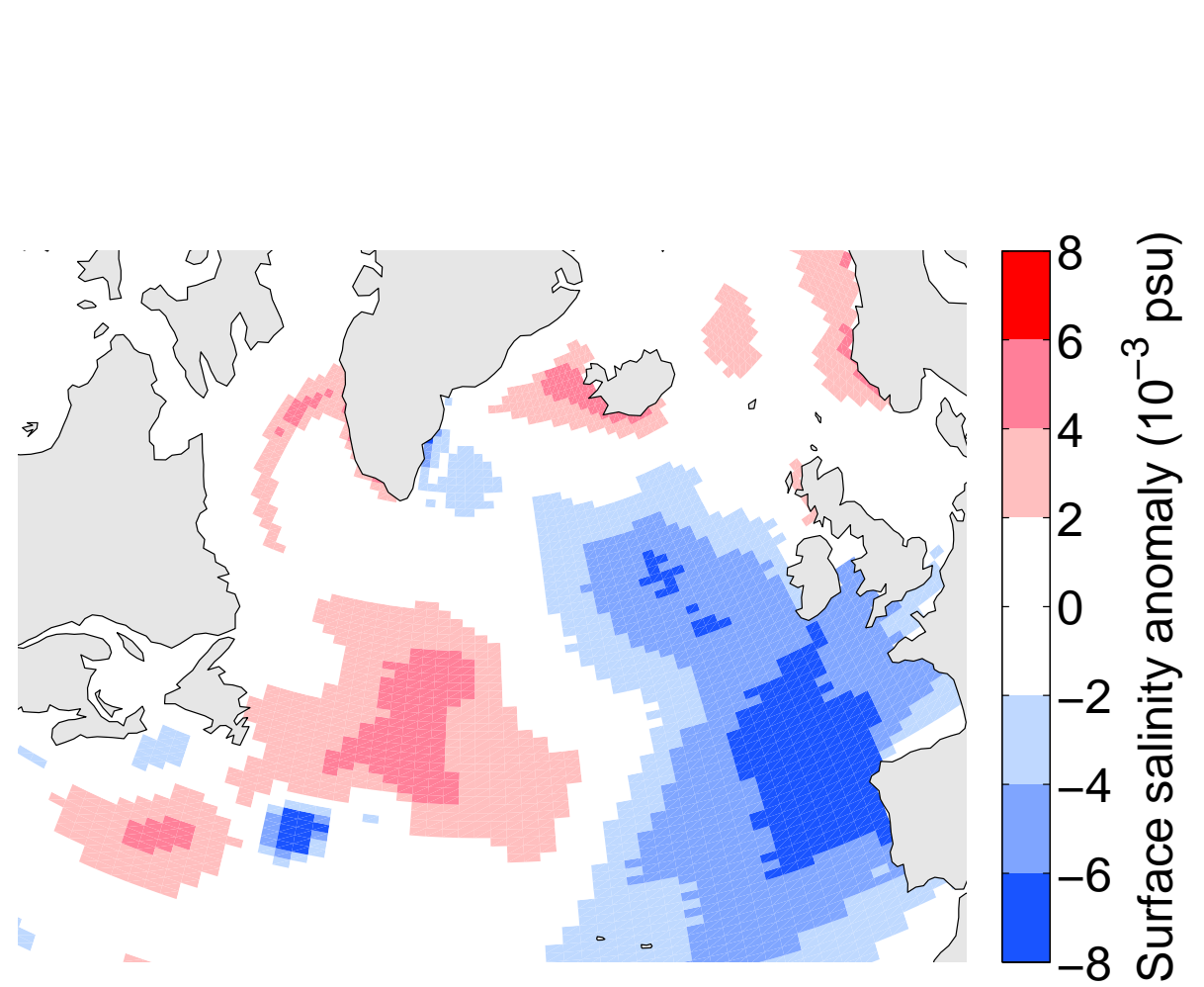

Fig. 6. Composite difference of salinity changes due to surface freshwater fluxes (evaporation minus precipitation) for $\mathrm{CCSM} 4$, based on the $\mathrm{SPG}_{\mathrm{AVE}}$ index (in psu). Although the anomaly pattern matches the observed changes in salinity, air-sea freshwater exchange can not explain the magnitude of the anomaly. The similarity of the pattern is due to changes in evaporation.

\section{OSD}

$10,555-579,2013$

\section{Salt transport in the Irminger Current}

\section{A. Born et al.}

\section{Title Page}

\section{Abstract}

Introduction

Conclusions

References

Tables

Figures

14

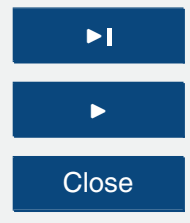

Full Screen / Esc

Printer-friendly Version

Interactive Discussion 


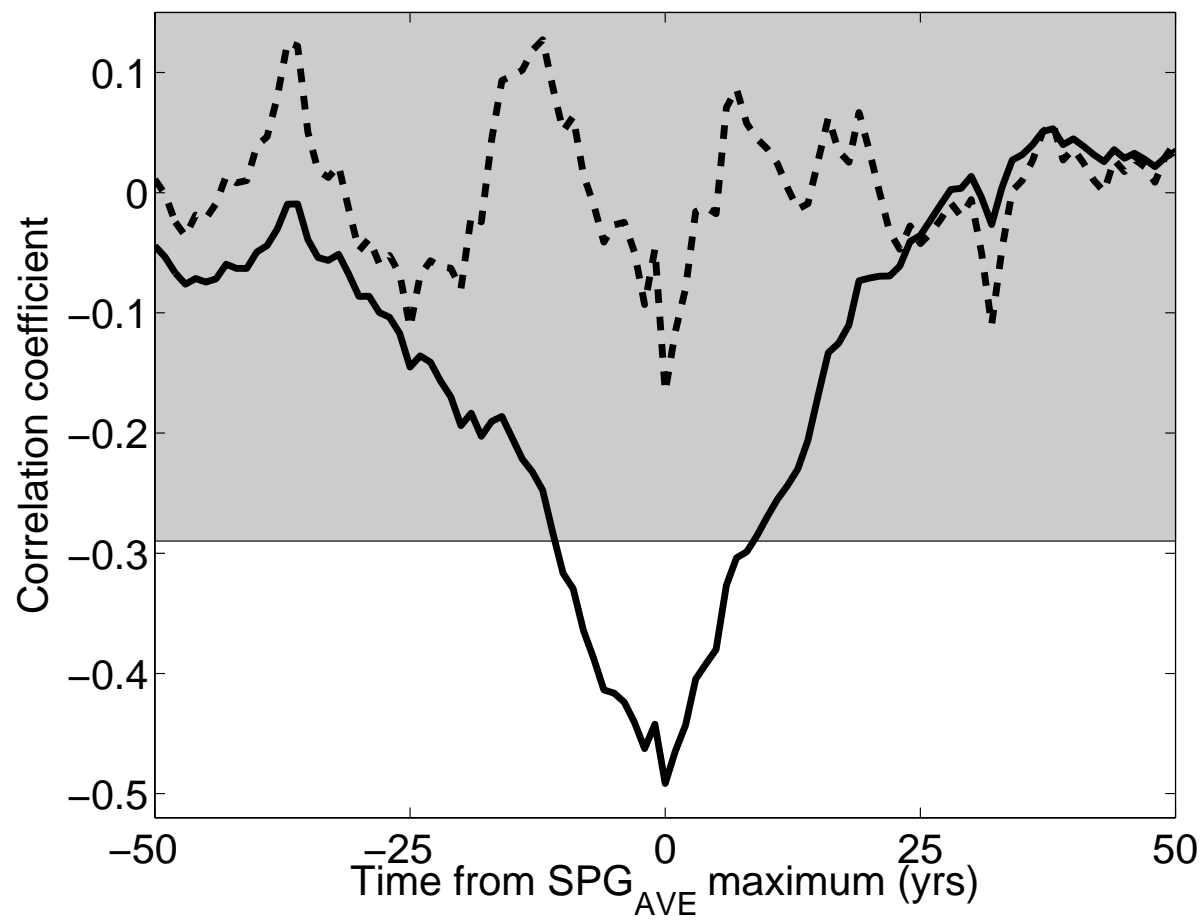

Fig. 7. Cross-correlation of $S P G_{A V E}$ and sea surface salinity in the SPG center (see Fig. 3) for CCSM4, for unfiltered data (solid) and high-pass filtered data, cut off at a period of $30 \mathrm{yr}$ (dashed). Shaded values are below the significance threshold, for 50 degrees of freedom.
OSD

$10,555-579,2013$

Salt transport in the Irminger Current
A. Born et al.

Title Page

\section{Abstract}

Introduction

Conclusions

References

Tables

Figures

14

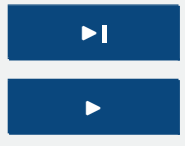

Back

Close

Full Screen / Esc

Printer-friendly Version

Interactive Discussion 